\title{
PODEM AS PEDAGOGIAS CRÍTICAS SUSTAR AS POLIITICAS DE DIREITA?
}

\author{
MICHAEL W. APPLE \\ Universidade de Wisconsin - Madison \\ apple@education.wisc.edu \\ Tradução: Maria Lúcia Mendes Gomes, \\ Regina Thompson e Vera Luiza Visockis Macedo*
}

\begin{abstract}
RESUMO
Grande parte da literatura sobre "pedagogias críticas" tem sido politica e teoricamente importante e nos ajudou a avançar em várias frentes. Com muita freqüência, no entanto, ela não tem sido relacionada o bastante com os modos pelos quais o atual movimento em direção ao que pode ser mais bem chamado de "modernização conservadora" alterou o senso comum e transformou as condições materiais e ideológicas que cercam o ensino. Desse modo, ela às vezes torna-se uma forma do que pode ser mais bem chamado de retórica do "romantismo das possibilidades", na qual a linguagem da possibilidade substitui uma análise habilidosa e consistente do que realmente é o equilibrio de forças e o que é necessário para mudar as políticas neoliberais e neoconservadoras na alfabetização e em toda a esfera da educação. Examino os modos pelos quais o terreno social e cultural da politica e do discurso educacionais tem sido alterado "in loco", por assim dizer. Afirmo que precisamos estabelecer conexões mais próximas entre nossos discursos teóricos e críticos, de um lado, e as transformações reais que estão atualmente deslocando políticas e práticas educacionais para direções fundamentalmente de direita, de outro. Desse modo, parte da minha discussão é conceitual e política; mas parte dela precisará ser de natureza empírica para que eu possa ordenar o que se conhece sobre os efeitos reais e materiais do deslocamento para a direita na educação.

POLITIICAS PÚBLICAS - CURRÍCULO - CULTURA
\end{abstract}

Este artigo baseia-se em uma análise muito mais extensa, encontrada em Michael W. Apple, 2001 .

* As tradutoras deste artigo são membros da Cooperativa de Profissionais em Tradução Unitrad (unitrad@unitrad.com.br). 


\begin{abstract}
CAN CRITICAL PEDAGOGIES INTERRUPT RIGHTIST POLICIES? Much of the literature on "critical pedagogies" has been politically and theoretically important and has helped us make a number of gains. However, it too often has not been sufficiently connected to the ways in which the current movement toward what might best be called "conservative modernization" both has altered common-sense and has transformed the material and ideological conditions surrounding schooling. It, thereby, sometimes becomes a form of what best be called "romantic possibilitarian" rhetoric, in which the language of possibility substitutes for a consistent tactical analysis of what the balance of forces actually is and what is necessary to change neo-liberal and neo-conservative policies in literacy and in the entire sphere of education. I examine the ways in which the social and cultural terrain of educational policy and discourse has been altered "on the ground" so to speak. I argue that we need to make closer connections between our theoretical and critical discourses on the one hand and the real transformations that are currently shifting educational policies and practices in fundamentally rightist directions on the other. Thus, part of my discussion is conceptual and political; but part of it will appropriately need to be empirical in order for me to pull together what is known about the real and material effects of the shift to the right in education.

PUBLIC POLICIES - CURRICULUM - CULTURE
\end{abstract}

\title{
MATERIALIDADES TERRENAS
}

Grande parte da literatura sobre "pedagogias críticas" tem sido política e teoricamente importante e nos ajudou a avançar em várias frentes. Com muita freqüência, no entanto, ela não tem sido suficientemente associada aos modos pelos quais o atual movimento em direção ao que pode ser chamado de "modernização conservadora" alterou o senso comum e transformou as condições materiais e ideológicas que cercam o ensino. Assim sendo, essa literatura às vezes se torna uma expressão da retórica do "romantismo das possibilidades", na qual a linguagem da possibilidade substitui uma análise consistente do que realmente é o equilíbrio de forças e o que é necessário para mudá-lo (Whitty, 1974).

Neste artigo, examino os modos pelos quais o terreno social e cultural da política e do discurso educacionais tem sido alterado in loco, por assim dizer. Afirmo que precisamos estabelecer conexões mais próximas entre nossos discursos teóricos e críticos, de um lado, e as transformações reais que estão atualmente deslocando políticas e práticas educacionais para direções fundamentalmente de direita, de outro. Desse modo, parte da minha discussão precisará ser conceitual; mas parte dela precisará ser de natureza empírica, para que eu possa ordenar o que se conhece sobre os efeitos reais e materiais do deslocamento para a direita na educação. 
Meu enfoque nas "materialidades terrenas" desses efeitos não pretende menosprezar a importância das intervenções teóricas. Tampouco pretende sugerir que os discursos dominantes não devam ser constantemente interrompidos pelos avanços alcançados por várias comunidades neomarxistas, pós-modernas, pós-estruturais, pós-coloniais, de homossexuais e outras. De fato, pedagogias críticas e revolucionárias exigema interrupção fundamental do senso comum. No entanto, embora a elaboração de novas teorias e visões utópicas seja importante, é igualmente crucial basear essas teorias e visões em uma avaliação não romântica do espaço material e discursivo existente hoje. O senso comum já está sendo radicalmente alterado, mas não em direções que nós da esquerda consideraríamos satisfatórias. Sem uma análise dessas transformações e do equilíbrio de forças que criou essas alterações incômodas, sem uma análise das tensões, das relações diferenciais de poder e das contradições inerentes a elas, tudo o que nos resta são novas formulações teóricas, cada vez mais refinadas, mas com uma compreensão menos do que refinada do campo de poder social no qual elas operam (Bourdieu, 1984).

\section{GUINADA PARA A DIREITA}

Em seu influente histórico de debates sobre currículos, Herbert Kliebard documentou que as questões educacionais normalmente envolveram grandes conflitos e concessões entre grupos com visões divergentes sobre o conhecimento "legítimo", sobre o que é considerado "bom" ensino e aprendizado e sobre o que seja uma sociedade "justa" (Kliebard, 1995). Trabalhos recentes, ainda mais críticos, ratificam que esses conflitos têm raízes profundas em visões conflitantes sobre justiça racial, de classe e gênero na educação e na sociedade como um todo (Rury, Mirel, 1997; Teitelbaum, 1996; Selden, 1999). Essas visões conflitantes nunca tiveram uma influência uniforme na imaginação dos educadores ou dos cidadãos como um grupo, tampouco, jamais tiveram poder uniforme para serem efetivadas. Por causa disso, nenhuma análise sobre a educação pode ser totalmente séria sem colocar em seu âmago mais profundo uma sensibilidade para com as batalhas que constantemente modelam o terreno no qual opera a educação.

Hoje não é diferente do passado. Formaram-se um "novo" conjunto de compromissos, uma nova aliança e um novo bloco de poder com crescente influência na educação e em todas as questões sociais. Esse bloco de poder combina múltiplas frações de capital comprometidas com soluções neoliberais mercantilizadas para problemas educacionais; intelectuais neoconservadores que desejam um "retorno"

a padrões mais elevados e a uma "cultura comum"; fundamentalistas religiosos 
populistas e autoritários profundamente preocupados com a secularidade e a preservação de suas próprias tradições; e determinadas frações de profissionais da nova classe média comprometidas com a ideologia e as técnicas de accountability *, avaliação e "gerenciamento". Embora existam tensões e conflitos evidentes no seio dessa aliança, de modo geral seus objetivos como um todo são os de fornecer as condições educacionais tidas como necessárias tanto para aumentar a competitividade, o lucro e a disciplina internacionais quanto para nos levar de volta a um passado romantizado da casa, da família e da escola "ideais" (Apple, 1996, 2000).

Em essência, a nova aliança integrou a educação a um conjunto mais amplo de compromissos ideológicos. Os objetivos na educação são os mesmos que guiam seus objetivos de bem-estar econômico e social. Eles incluem a dramática expansão daquela ficção eloqüente, o livre mercado; a drástica redução da responsabilidade governamental para com as necessidades sociais; o fortalecimento de estruturas altamente competitivas de mobilidade tanto dentro quanto fora da escola; o rebaixamento das expectativas das pessoas quanto à segurança econômica; o "disciplinamento" da cultura e do corpo; e a popularização do que é claramente uma forma de pensamento social darwinista, como indica, de modo óbvio e angustiante, a recente popularidade de The Bell Curve (Herrnstein, Murray, 1994; ver também Kincheloe, Steinberg, Greeson, 1997).

O discurso aparentemente contraditório sobre concorrência, mercados e escolhas, de um lado, e prestação de contas, objetivos de desempenho, padrões, exames e currículos nacionais, de outro, criou tamanha gritaria que é difícil conseguir ouvir qualquer outra coisa. Como mostrei em Cultural politics and education ( 1996), essas tendências, na verdade, estranhamente reforçam-se umas às outras e ajudam a consolidar posições educacionais conservadoras nas nossas vidas diárias.

Embora lamentáveis, as mudanças que estão ocorrendo apresentam oportunidade excepcional para uma séria reflexão crítica. Em uma época de mudanças sociais e educacionais radicais, é fundamental documentar os processos e efeitos dos vários e, algumas vezes, contraditórios elementos da restauração conservadora e dos modos pelos quais eles são mediados, resolvidos, aceitos, utilizados de maneiras diferentes por grupos diferentes para seus propósitos, e/ou combatidos nas

* Entende-se, pelo termo, a prestação de contas feita à população, referente a um serviço realizado ou delegado pelo poder público. Ela tem o intuito de tornar transparente aos interessados o modo como são empregados os recursos provenientes de suas contribuições (N. da E.). 
políticas e práticas do cotidiano educacional das pessoas. (Ranson, 1995). Neste artigo, gostaria de dar uma idéia de como isso pode ocorrer em "reformas" atuais, como a mercantilização da educação, os currículos e os exames nacionais. Para aqueles interessados em políticas e práticas educacionais críticas, deixar de fazer isso significa agir sem compreender as relações do deslocamento de poder que estão construindo e reconstruindo o campo social do poder. Embora a frase de Gramsci, "Pessimismo da inteligência, otimismo da vontade", tenha uma poderosa repercussão e seja útil para a mobilização e para não perdermos a esperança, seria tolice substituir uma análise mais profunda, sem dúvida necessária se quisermos ser bemsucedidos, por slogans retóricos.

\section{NOVOS MERCADOS, VELHAS TRADIÇÕES}

Por trás de grande parte do conjunto discursivo da nova direita havia uma posição que enfatizava "uma construção culturalista da nação como um refúgio (ameaçado) para as tradições e valores brancos (cristãos)", no dizer de Gillborn ( 1997, p. 2). Isso envolveu a construção de um passado nacional imaginário que é pelo menos parcialmente mitificado, e depois é empregado para criticar o presente. Gary McCulloch afirma que a natureza das imagens históricas da educação mudou. $\bigcirc$ imaginário dominante da educação como sendo "segura, domesticada e progressista" (isto é, como se essa educação conduzisse ao progresso e ao aperfeiçoamento social/pessoal) foi alterado para uma educação "ameaçadora, alienada e retrógrada" ( 1997 , p. 80). O passado não é mais fonte de estabilidade, mas marca de fracasso, desapontamento e perda. Isso pode ser observado de maneira mais vívida nos ataques à "ortodoxia progressista" que supostamente hoje reina suprema nas salas de aula de muitos países (Hirsch, 1996).

Por exemplo, na Inglaterra - embora o mesmo discurso ecoe em grande parte nos Estados Unidos, na Austrália e em outros lugares - Michael Jones, o editor de política do The Sunday Times, recorda-se da escola primária de seu tempo.

A escola primária foi uma época feliz para mim. Éramos cerca de 40 alunos, sentados em mesas fixas de madeira, com tinteiros, e de lá saímos somente com permissão relutante. A professora sentava-se em uma mesa mais alta, defronte a nós, e movimentava-se somente até a lousa. Ela cheirava a perfume e inspirava respeito. (McCulloch, 1997, p. 78)

A mistura de metáforas que invocam disciplina, perfume (visceral e quase "natural") e respeito é fascinante. Mas ele continua, lamentando os últimos 30 anos 
de "reforma" que transformaram as escolas primárias. Falando da experiência de seus filhos, Jones diz:

Meus filhos passaram seus primeiros anos escolares em uma escola 'espetacular onde tinham autorização para vaguear à vontade, desenvolver sua individualidade real e esquivarem-se dos "3Rs" [em inglês, rights, responsibility, respect. direitos, responsabilidade, respeito]. Tudo isso era para o melhor, nos asseguravam. Mas não foi. (Apud McCulloch, 1997, p. 78)

Para Jones, a "ortodoxia dogmática" da educação progressista "levou diretamente ao declínio educacional e social". Somente as reformas de direita instituídas nas décadas de 1980 e 1990 poderiam deter e depois reverter esse declínio. Somente assim o passado imaginado poderia retornar.

O cenário é mais ou menos o mesmo deste lado do Atlântico. Esses sentimentos ecoam nos pronunciamentos públicos de figuras como Bennett, Hirsch e outros; todos eles parecem acreditar que o progressivismo é atualmente a posição dominante na política e prática educacionais e destruiu um passado valoroso. Todos eles acreditam que somente intensificando o controle sobre os currículos e o ensino (e sobre os alunos, é claro), restaurando "nossas" tradições perdidas, tornando a educação mais disciplinada e competitiva - como estão certos de que ela era no passado -, somente assim poderemos ter escolas eficazes. A essas pessoas juntamse outras que têm críticas similares, mas que, ao contrário, voltam-se para um passado diferente com vistas a um futuro diferente. Seu passado não é tanto aquele do perfume, do respeito e da autoridade, mas um passado de "liberdade" de mercado. Para eles, nada pode ser realizado - nem mesmo a restauração do respeito e da autoridade - sem a implantação da livre expressão do mercado nas escolas, de modo a garantir que apenas as "boas" sobrevivam.

Devemos entender que essas políticas são transformações radicais. Se tivessem vindo do outro lado do espectro político, teriam sido ridicularizadas de diversas maneiras, dadas as tendências ideológicas das nossas nações. Além do mais, tais políticas baseiam-se em um passado bucólico romantizado, e as reformas não se têm destacado por estar fundamentadas em resultados de pesquisas. De fato, quando utilizada, essa pesquisa quase sempre serviu como uma retórica de justificação para crenças preconcebidas sobre a suposta eficácia dos mercados ou de regimes de estrita responsabilização dos agentes educacionais ou baseou-se em estudos bastante falhos, como no caso do trabalho de Chubb e Moe (1990) sobre a introdução da lógica de mercado nas escolas (Ver também Whytty, 1997). 
No entanto, não importa o quão radicais sejam algumas dessas propostas de "reformas", e não importa o quão fraca seja sua base empírica de sustentação, elas redefiniram o terreno do debate sobre tudo o que seja educacional. Depois de anos de ataques e mobilizações conservadoras, ficou claro que "idéias antes tidas como imaginativas, impraticáveis ou simplesmente extremas" estão hoje cada vez mais sendo vistas como senso comum (Gillborn, 1997a, p. 357).

Do ponto de vista tático, o avanço alcançado na reconstrução do senso comum provou ser extremamente eficaz. Por exemplo, há estratégias claramente discursivas sendo empregadas aqui, as que se caracterizam por "falar com clareza" e usar uma linguagem que "todos possam entender". (Não desejo ser totalmente negativo a respeito. A importância dessas coisas é algo que muitos educadores "progressistas", inclusive muitos autores da pedagogia crítica, ainda têm de entender; ver Apple, 1999 e 1998). Essas estratégias envolvem não apenas a apresentação de posições pessoais como "senso comum", como também em geral significam, tacitamente, que há uma certa conspiração entre os oponentes de uma posição para negar a verdade ou para dizer somente aquilo que está "na moda", como observa Gillborn:

Trata-se de uma técnica poderosa. Primeiro, ela assume que não há argumentos genuínos contra a posição escolhida; quaisquer visões contrárias são desse modo posicionadas como falsas, insinceras ou autocentradas. Segundo, a técnica apresenta o orador como alguém corajoso ou honesto o suficiente para falar o (antes) indizível. A partir daí, assume-se a superioridade moral, e os adversários são ainda mais denegridos. (1997a, p. 353)

É difícil deixar de ver essas características em algumas publicações da literatura conservadora, como as de Herrnstein e Murray ( 1994), da "verdade" impensável sobre a genética e a inteligência ou a discussão "inflexível" mais recente de Hirsch ( 1996 ) sobre a destruição do ensino "sério" por educadores progressistas.

\section{MERCADOS E DESEMPENHO}

Vamos tomar um elemento da modernização conservadora como exemplo das maneiras como tudo isso opera - a afirmação neoliberal que a mão invisível do mercado resultará inexoravelmente em escolas melhores. Como nos lembra Roger Dale, "o mercado" atua como uma metáfora mais do que como um guia explícito para a ação. Ele não é denotativo, mas sim conotativo. Assim, o próprio mercado tem de ser "vendido" para aqueles que nele existirão e viverão com seus efeitos. Os 
mercados são transformados em mercadoria, são legitimados por uma estratégia despolitizante. São tidos como naturais e neutros e governados pelo esforço e pelo mérito. E aqueles que se opõem a eles opõem-se também, por definição e a partir daí, ao esforço e ao mérito. Os mercados, do mesmo modo, estão supostamente menos sujeitos à interferência política e ao peso dos procedimentos burocráticos. Além disso, baseiam-se nas escolhas racionais dos atores individuais (apud Mentor et al., 1997, p. 27). Assim, os mercados e a garantia de recompensas pelo esforço e pelo mérito devem ser combinados para produzir resultados "neutros", porém positivos. Os mecanismos, a partir daí, têm de ser colocados em ação de modo a dar provas de eficiência e de eficácia empresariais. Essa união dos mercados e dos mecanismos para a geração de evidências de desempenho é exatamente o que ocorreu. Se funciona ou não, está aberto para ser questionado.

Em uma das análises críticas mais abrangentes de todas as evidências da mercantilização da educação, Geoff Whitty nos alerta para não confundirmos a retórica com a realidade. Após analisar pesquisas realizadas em vários países, Whitty argumenta que, embora os defensores dos planos de "escolha" mercantilizados assumam que a concorrência aumentará a eficiência e a receptividade das escolas, assim como dará às crianças desfavorecidas oportunidades que elas atualmente não possuem, isso pode ser uma falsa esperança. Essas esperanças não estão sendo realizadas e é improvável que o sejam no futuro, "no contexto de políticas mais amplas que não fazem nada para questionar desigualdades sociais e culturais mais profundas". Assim ele continua: "A tomada de decisão atomizada em uma sociedade altamente estratificada pode dar a falsa ilusão de que dá oportunidades iguais a todos; mas transferir a responsabilidade da tomada de decisão da esfera pública para a privada pode, na verdade, reduzir o escopo da ação coletiva na busca de uma educação de melhor qualidade para todos". Quando se relaciona isso ao fato de que, na prática, as políticas neoliberais que envolvem "soluções" de mercado podem, na verdade, servir para reproduzir - não para subverter - as hierarquias tradicionais de classe e raça, isso deve ser suficiente para nos fazer parar (Whitty, 1997, p. 58; ver também Whitty, Edwards, Gewirtz, 1993).

Desse modo, em vez de aceitar as afirmações neoliberais exatamente como elas se apresentam, sem questioná-las, devemos indagar sobre seus efeitos ocultos que, com muita freqüência, ficam invisíveis na retórica e nas metáforas de seus defensores. Diante das limitações do que se pode dizer em um artigo deste porte, selecionarei umas poucas questões que têm recebido menos atenção do que merecem, mas sobre as quais há hoje um número expressivo de pesquisas. 
A experiência inglesa é apropriada neste caso, em especial porque os defensores do mercado, como Chubb e Moe (1990), dependem substancialmente dela e também porque é na Inglaterra em que essas tendências estão mais avançadas. A Lei de Educação inglesa, de 1993, instrui sobre o compromisso de mercantilização do Estado. Órgãos governamentais de educação das localidades receberam o mandato para considerar formalmente a necessidade de "irem para o mercado" (isto é, de desistirem do controle do sistema escolar local e entrarem no mercado competitivo) a cada ano (Power, Halpin, Fitz, 1994, p. 27). Assim, nesse caso, a pressão em direção às reformas neoliberais foi exercida pelo Estado'. No entanto, ao invés de resultar em uma abertura e diversificação dos currículos, o mercado competitivo não criou muita coisa diferente dos modelos tradicionais tão firmemente enraizados nas escolas de hoje (Power, Halpin, Fitz, 1994; Gillborn, Youdell, 2000). Nem alterou de modo radical as relações de desigualdade que caracterizam o ensino.

Em suas análises detalhadas sobre os efeitos "na vida real" das reformas que introduzem a lógica de mercado na educação, Ball e seus colaboradores indicam algumas das razões pelas quais precisamos ser bastante cautelosos nesse ponto. Como documentam, nessas situações os princípios e valores educacionais terminam quase sempre comprometidos pelas questões comerciais, que ganham maior importância na elaboração dos currículos e na alocação de recursos (Ball, Bowe, Gewirtz, 1994, p. 39). Por exemplo, a junção da perspectiva de mercado com a demanda e a publicação de indicadores de desempenho na forma de ranking de escolas ${ }^{2}$, na Inglaterra, levou as escolas a procurarem cada vez mais maneiras de atrair pais "motivados", com filhos "capazes". Nesse caso, as escolas podem aprimorar sua posição relativa nos sistemas locais de concorrência. Isso representa um deslocamento sutil, mas crucial, na ênfase das necessidades do aluno para o desempenho do aluno e na importância do que a escola faz para o aluno para a importância do que o aluno faz pela escola, o que não é discutido abertamente com a fre-

I. Se está havendo mudanças significativas a esse respeito, considerando-se a vitória do Novo Trabalhismo sobre os conservadores na última eleição, é algo sujeito a questionamentos. Alguns aspectos das políticas neoliberais e neoconservadoras já foram aceitos pelo Partido Trabalhista, como a aceitação de controles rigorosos de custos sobre os gastos realizados pelo anterior governo conservador e um enfoque agressivo sobre a elevação de padrões juntamente com rigorosos indicadores de desempenho.

2. A classificação oficial das escolas segundo o rendimento dos alunos, que permite a sua comparação e orienta a atribuição de recursos pelo poder público, pode ocasionar a diminuição de subsídios para aquelas que apresentam piores resultados. 
qüência que deveria ser. Isso também é acompanhado, com uma freqüência inquietante, por um deslocamento de recursos destinados a alunos rotulados como especiais ou com dificuldades de aprendizagem, para marketinge relações públicas. Alunos com "necessidades especiais" não só significam altos custos, como também significam redução nas pontuações obtidas nos testes daquela tão importante classificação das escolas.

Isso não apenas dificulta "administrar as impressões do público", como também dificulta atrair os "melhores" e mais talentosos professores em termos acadêmicos (Ball, Bowe, Gewirtz, 1994, p. 17-19). No entanto, todo o empreendimento, de fato, estabelece uma nova métrica e um novo conjunto de objetivos, com base em uma competição constante para ganhar o jogo do mercado. É importante o que isso significa, não apenas em termos dos seus efeitos no dia-a-dia da escola, como também no modo como se altera o que é considerado uma boa sociedade e um cidadão responsável. Permitam-me dizer algo sobre isso.

Observei anteriormente que por trás de todas as propostas educacionais estão visões de uma sociedade justa e de um bom aluno. As reformas neoliberais que tenho discutido constroem isso de um modo particular. Embora a característica definidora do neoliberalismo esteja em grande parte baseada nos princípios centrais do liberalismo clássico, em particular do liberalismo econômico clássico, existem diferenças cruciais entre o liberalismo clássico e o neoliberalismo. Essas diferenças são absolutamente essenciais para compreender a política da educação e as transformações pelas quais a educação está atualmente passando. Mark Olssen detalha claramente essas diferenças no trecho a seguir. Vale a pena citá-lo na íntegra.

Considerando-se que o liberalismo clássico representa uma concepção negativa do poder do Estado, no sentido em que o indivíduo era tido como um objeto a ser libertado das intervenções do Estado, o neoliberalismo surgiu para representar uma concepção positiva do papel do Estado na criação do mercado apropriado, ao oferecer as condições, as leis e as instituições necessárias para sua operação. No liberalismo clássico, o indivíduo é caracterizado como tendo uma natureza humana autônoma e pode praticar a liberdade. No neoliberalismo, o Estado procura criar um indivíduo que seja um empreendedor audacioso e competitivo. No modelo clássico, o objetivo teórico do Estado era o de limitar e minimizar seu papel com base em postulados que incluíam o egoísmo universal (o indivíduo interessado em si próprio); a teoria da mão invisível que ditou que os interesses do indivíduo também eram os interesses da sociedade como um todo; e a máxima política do laissez-faire. Na mudança do liberalismo clássico para o neoliberalismo, acrescenta-se mais um elemento, pois tal mudança envolve uma alteração na posição do sujeito de homo 
economicus, que naturalmente se comporta a partir de seu interesse pessoal e é relativamente distanciado do Estado, para o "homem manipulável", criado pelo Estado e constantemente encorajado a ser "eternamente responsivo". Isso não significa que a concepção do sujeito interessado em si próprio seja substituída ou eliminada pelos novos ideais do "neoliberalismo"; mas que, em uma era de bem-estar universal, as possibilidades entendidas como indolência preguiçosa criam necessidades de novas formas de vigilância, fiscalização, "avaliação do desempenho" e outras formas de controle de modo geral. Nesse modelo, o Estado decidiu manter todos dentro de determinados padrões de qualidade. $\bigcirc$ Estado tomará as medidas para que cada um faça de si próprio uma "empresa contínua"... no que parece ser um processo de "governar sem governar". (1996, p. 340)

Os resultados da pesquisa de Ball e seus colegas documentam como o Estado faz isso de fato, realçando aquela combinação peculiar de controle e individualismo mercantilizado, e por meio da avaliação pública constante e comparativa. $\bigcirc$ ranking das escolas, amplamente divulgado, determina o valor relativo das pessoas no mercado educacional. Somente aquelas escolas com indicadores de desempenho cada vez mais altos são respeitáveis. E somente aqueles alunos capazes de "fazer uma empresa constante de si próprios" podem manter tais escolas na direção "correta". No entanto, embora essas questões sejam importantes, elas não conseguem iluminar completamente alguns dos outros mecanismos pelos quais efeitos diferenciais são produzidos pelas reformas neoliberais. Aqui, as questões de classe vêm à tona, como deixam claro Ball, Bowe e Gewirtz.

Os pais da classe média são, sem dúvida, os que mais se beneficiam desse tipo de montagem cultural, e não apenas, como vimos, porque as escolas os procuram. De modo geral, os pais da classe média tornaram-se bastante habilidosos para explorar os mecanismos de mercado na educação e neles aplicar seu capital social, econômico e cultural. "Os pais da classe média têm maior probabilidade de ter o conhecimento, as habilidades e os contatos para decodificar e manipular o que são sistemas cada vez mais complexos e desregulamentados de escolha e recrutamento. Quanto mais desregulamentação, maior a possibilidade de procedimentos informais serem empregados. A classe média também, como um todo, é mais capaz de movimentar seus filhos ao redor do sistema" (Ball, Bowe, Gewirtz, 1994, p. 19). 0 fato de que classe e raça cruzam-se e interagem de maneiras complexas significa que os resultados diferenciais serão "naturalmente" raciais e também de classe embora precise ficar claro que sistemas de mercado na educação quase sempre têm sua razão de ser, consciente e inconsciente, no medo do "Outro" e quase sempre são expressões ocultas de uma "racialização" da política educacional (Omi, 
Winant, 1994; McCarthy, Crichlow, 1994; McCarthy, 1998). O capital econômico e social pode ser convertido em capital cultural de várias maneiras. Em planos mercantilizados, pais com maior poder aquisitivo quase sempre têm horários mais flexíveis e podem visitar várias escolas. Eles possuem automóveis - quase sempre mais do que um - e podem arcar com os custos de levar seus filhos de carro para freqüentar uma escola "melhor". Podem também fornecer os recursos culturais implícitos em acampamentos e programas para depois da escola (dança, música, aulas de informática etc.), que proporcionem a seus filhos um "bem-estar", um "estilo" que parece "natural" e funciona como um conjunto de recursos culturais. Sua provisão anterior de capital social e cultural - as pessoas que conhecem, o fato de que ficam à vontade em encontros sociais com funcionários da área da educação - é uma mina invisível de recursos, porém poderosa. Assim, pais mais prósperos têm maior probabilidade de ter o conhecimento e a habilidade informais - o que Bourdieu (1984) chamaria de habitus - para serem capazes de decodificar e utilizar formas mercantilizadas em seu próprio benefício. Essa percepção do que pode ser chamado de "segurança" - que é em si o resultado de escolhas passadas que tacitamente (mas não com menos poder) dependeram dos recursos econômicos que lhes asseguraram de fato a capacidade de fazer escolhas econômicas - é o capital invisível que respalda a capacidade de negociar formas mercantilizadas e "trabalhar o sistema" por meio de conjuntos de regras culturais informais (Ball, Bowe, Gewirtz, 1994, p. 20-22).

É claro, é preciso ser dito que a classe trabalhadora, os pais pobres e/ou imigrantes não são, de nenhum modo, menos habilidosos nesse aspecto. Afinal, é necessário enorme habilidade, coragem e recursos sociais e culturais para sobreviver em condições materiais de exploração e depressão. Assim, aqui, laços coletivos, redes e contatos informais e a habilidade para trabalhar o sistema são desenvolvidos de maneiras bastante matizadas, inteligentes e quase sempre impressionantes, conforme Fine e Weis, 1998 e Dunier, 1999. No entanto, a combinação entre o habitus historicamente enraizado - que é esperado nas escolas e em seus atores e naqueles dos pais mais prósperos - e os recursos materiais disponíveis a pais mais prósperos normalmente leva a uma conversão bem-sucedida do capital econômico e social no capital cultural (Bourdieu, 1996; Swartz, 1997). E isso é exatamente o que está ocorrendo na Inglaterra.

Essas afirmações sobre o que está acontecendo no interior das escolas, assim como sobre conjuntos mais amplos de relações de poder, são respaldadas por análises recentes ainda mais sintéticas dos resultados totais dos modelos mercantilizados. 
Pesquisa sobre os efeitos da combinação tensa, mas ainda eficaz, de políticas neoliberais e neoconservadoras examina tendências internacionais, comparando o que aconteceu em vários países - por exemplo, nos Estados Unidos, na Inglaterra e no País de Gales, na Austrália e na Nova Zelândia - nos quais essa combinação tem sido cada vez mais intensa. Os resultados confirmam as afirmações feitas neste trabalho. Permitam-me enumerar algumas das descobertas mais significativas e inquietantes dessa pesquisa.

Infelizmente, é bastante comum que as medidas mais amplamente utilizadas do "sucesso" das reformas educacionais sejam o resultado de testes de desempenho padronizados. Isso simplesmente não funciona. Precisamos perguntar constantemente o que as reformas fazem para as escolas como um todo e para cada um de seus participantes, incluindo professores, alunos, administradores, membros da comunidade, ativistas locais e assim por diante. Para tomarmos um conjunto de exemplos, à medida que as escolas mercantilizadas "auto-administradas" crescem em muitos países, o papel do diretor da escola é radicalmente transformado. Mais poder é realmente concentrado no seio da estrutura administrativa. Mais tempo e energia são despendidos na manutenção ou aprimoramento da imagem pública de uma "boa escola" e menos tempo e energia são despendidos na essência pedagógica e curricular. Ao mesmo tempo, os professores parecem experimentar não o aumento da autonomia e do profissionalismo, mas sua intensificação (Apple, 1988, p. I|3-136). E, estranhamente, como observado antes, as próprias escolas tornam-se mais similares e mais comprometidas com métodos padronizados e tradicionais de ensino, que abordam a classe como um todo, bem como com um currículo padrão e tradicional, quase sempre monocultural. Dirigir nossa atenção apenas para resultados de testes faria com que deixássemos de perceber algumas transformações realmente profundas, muitas das quais podemos considerar inquietantes.

Uma das razões de esses efeitos serem produzidos com tanta freqüência é que, em muitos países, as visões neoliberais de quase-mercados são normalmente acompanhadas de pressões neoconservadoras para regular o conteúdo e o comportamento por meio de instrumentos como currículos nacionais, padrões nacionais e sistemas nacionais de avaliação. A combinação é historicamente casual; isto é, não é absolutamente necessário que as duas ênfases sejam combinadas. Mas existem características do neoliberalismo que fazem com que seja mais provável que uma ênfase no Estado fraco e uma crença nos mercados seja mais coerente com uma ênfase no Estado forte e no compromisso de regular o conhecimento, os valores e o corpo. 
Isso ocorre em parte devido ao poder cada vez maior do "Estado avaliador", o que inicialmente pode ser visto como resultado de tendências contraditórias. Ao mesmo tempo em que o Estado parece estar transferindo poder para os indivíduos e para as instituições autônomas, e elas próprias cada vez mais concorrendo em um mercado, o Estado permanece forte nas áreas essenciais. Como já afirmei, uma das principais diferenças entre o liberalismo clássico, e sua crença em "indivíduos empreendedores" e no mercado, e as atuais formas de neoliberalismo é o compromisso deste último com um Estado regulador. $\bigcirc$ neoliberalismo realmente exige a constante produção de evidências de que as pessoas estão de fato "fazendo uma empresa de si próprias" (Olssen, 1996). Assim, sob essas condições, não apenas a educação torna-se uma mercadoria vendável, como pão e carros, na qual os valores, procedimentos e metáforas comerciais dominam, como também seus resultados têm de ser redutíveis a "indicadores de desempenho" padronizados (Clark, Newman, 1997). Isso se encaixa de modo ideal à tarefa de fornecer um mecanismo para as tentativas neoconservadoras de especificar quais conhecimentos, valores e comportamentos devem ser padronizados e oficialmente definidos como "legítimos", um aspecto no qual me estenderei na próxima seção.

Em essência, estamos testemunhando um processo no qual o Estado transfere a culpa pelas desigualdades, bastante evidentes no acesso e nos resultados que prometeu reduzir, de si para as escolas, pais e filhos. Isso, é claro, também faz parte de um processo mais amplo no qual os grupos econômicos dominantes transferem para o Estado a culpa pelos efeitos maciços e desiguais de suas próprias decisões equivocadas. $\bigcirc$ Estado, então, defronta-se com uma crise bastante real de sua legitimidade. Considerando isso, não devemos de modo algum nos surpreender que o Estado, então, procure exportar essa crise para fora de si (Apple, 1995).

Com certeza, o Estado é não apenas classista, mas inerentemente sexista e racista (Omi, Winant, 1994; Epstein, Johnson, 1998; Middleton, 1998). Isso fica claro nos argumentos de Whitty, Power e Halpin. Eles apontam para a natureza sexista dos modos pelos quais a administração das escolas é pensada, como modelos comerciais "masculinistas" tornam-se cada vez mais dominantes (Whitty, Power, Halpin, 1998). Embora haja o perigo de essas afirmações degenerarem em argumentos reducionistas e essencializantes, há uma boa dose de acuidade nessas colocações. Elas são coerentes com o trabalho de outros acadêmicos, da educação e de outras áreas, que reconhecem que os modos pelos quais nossas próprias definições de público e privado, de qual conhecimento tem mais valor e de como as instituições devem ser pensadas e administradas, estão completamente comprometidos 
com a natureza de gênero dessa sociedade (Entre os melhores trabalhos sobre o tema, consulte-se Fraser, 1989 e 1997). Esses efeitos ideológicos amplos - possibilitando, por exemplo, a formação de uma coalizão entre neoliberais e neoconservadores, a masculinização de teorias, políticas e assuntos administrativos - são de considerável importância e dificultam mudar o senso comum em direções mais críticas.

Outros efeitos mais imediatos dentro das escolas também chamam a atenção. Por exemplo, embora os diretores pareçam deter maior poder local nas escolas supostamente descentralizadas, a cristalização das políticas neoconservadoras faz com que eles "sejam cada vez mais forçados a assumir uma posição em que têm de demonstrar um desempenho coerente com currículos determinados pelo centro, em um contexto sobre o qual têm cada vez menos poder". Tanto os diretores quanto os professores vêem-se sobrecarregados de trabalho, além de serem obrigados a assumir cada vez mais responsabilidades, a comparecer a um número sem fim de reuniões e, em muitos casos, a enfrentar uma carência cada vez maior de recursos emocionais e físicos (Whitty, Power, Halpin, 1998).

Além disso, assim como ocorreu na Inglaterra, em quase todos os países estudados o mercado não estimulou a diversidade no currículo, na pedagogia, na organização, na clientela ou até mesmo na imagem. Pelo contrário, desvalorizou sistematicamente as alternativas, ampliando o poder dos modelos dominantes. Igualmente, exacerbou sistematicamente as diferenças no acesso e nos resultados, com base na raça, grupo étnico e classe ${ }^{3}$, como demonstram Gillborn e Youdell (2000).

O retorno ao "tradicionalismo" gerou uma série de conseqüências. Deslegitimou modelos mais críticos de ensino e aprendizagem, um ponto crucial a ser considerado em qualquer tentativa de avaliação das possibilidades de lutas culturais e implantação de pedagogia crítica nas escolas. Reintroduziu a reestratificação dentro da escola e diminuiu a possibilidade de ocorrerem desvios. Deu-se maior ênfase a crianças "dotadas" e classes que "aprendem rápido", enquanto os alunos considerados menos capazes do ponto de vista acadêmico foram vistos como "menos interessantes". Na Inglaterra as conseqüências se fizeram sentir, mais do que em qualquer outro aspecto, no alarmante índice de alunos excluídos da escola. Isso

3. É importante salientar aqui que isso tem ocorrido constantemente, mesmo diante de tentativas evidentes de se usarem essas políticas para mudar as desigualdades existentes. 
ocorreu em grande parte devido à intensa pressão para se demonstrar continuamente índices mais elevados de desempenho, principalmente em contextos mercantilizados, nos quais "a principal força motriz parecia ser de caráter comercial em lugar de educacional" (Whitty, Power, Halpin, 1998).

$\mathrm{Na}$ análise que fizeram sobre esses resultados inquietantes e mais mascarados, Whitty, Power, e Halpin e outros demonstram que, dentre os perigosos efeitos de uma situação de quase-mercado, situam-se as formas pelas quais as escolas que desejam manter ou ampliar sua posição no mercado "peneiram" para garantir que determinados tipos de alunos, com características específicas, sejam aceitos, enquanto outros tipos de alunos são considerados insuficientes. Em algumas escolas, os estereótipos foram reproduzidos de forma que as meninas fossem vistas como mais valiosas, assim como alunos de certas comunidades asiáticas. Crianças afrocaribenhas quase sempre eram consideradas fracassadas nessa situação (Gillborn, Youdell, 2000; Gewirtz, Ball, Bowe, 1995).

Até agora, concentrei-me basicamente no caso da Inglaterra. No entanto, como mencionei na introdução, esses movimentos são, na verdade, globais. Sua lógica disseminou-se rapidamente por várias nações, com resultados que tendem a refletir aqueles analisados até o presente. $O$ caso da Nova Zelândia cabe bem aqui, principalmente se considerarmos que uma grande porcentagem da população do país é multiétnica e que a nação tem uma história de tensões e desigualdades raciais. Além disso, a mudança para políticas da nova direita ocorreu mais rapidamente que em qualquer outro lugar. Basicamente, a Nova Zelândia tornou-se o laboratório para diversas das políticas aqui analisadas. Em seu excepcional estudo, baseado em grande parte em um mecanismo conceitual influenciado por Pierre Bourdieu, Lauder e Hughes comprovaram que os mercados da educação parecem provocar uma redução geral nos padrões educacionais. Paradoxalmente, esses mercados exercem um efeito negativo, e não positivo, sobre o desempenho de escolas com grandes populações de classes trabalhadoras e minorias. Em essência, "transferem as oportunidades de crianças menos privilegiadas para aquelas que já são privilegiadas" (Lauder, Hughes, 1999, p. 2). A combinação das políticas neoliberais de mercantilização e a ênfase neoconservadora em "padrões mais rígidos", sobre os quais discorrerei na próxima seção, criam um conjunto de condições ainda mais perigosas. A análise dos autores confirma os argumentos conceituais e empíricos de Ball, Phil Brown e outros, de que os mercados de educação não se referem somente à reação do capital para reduzir tanto a esfera do Estado quanto o controle público. Os mercados fazem parte também da tentativa da classe média de alterar as 
regras da competitividade na educação, em vista da maior insegurança que seus filhos enfrentam. "Ao mudar o processo de seleção para ingresso nas escolas, os pais da classe média conseguem aumentar o interesse na criação de mecanismos mais fortes de exclusão da classe trabalhadora e comunidades pós-coloniais em sua luta por igualdade de oportunidades" (Brown, 1997, p. 29).

Os resultados observados na Nova Zelândia não só refletem aquilo que foi observado em outros lugares, como também demonstram que quanto mais a prática segue a lógica da ação personificada nos princípios de mercantilização, pior a situação tende a se tornar. Os mercados sistematicamente privilegiam as famílias de nível socioeconômico mais elevado, por meio de seu conhecimento e recursos materiais. Essas são as famílias que têm mais probabilidade de fazer escolhas. Em lugar de permitir que a grande quantidade de alunos provenientes da classe trabaIhadora, pobres ou "de cor" deixe a escola, na sua grande maioria são as famílias de nível socioeconômico mais elevado que deixam as escolas públicas e escolas com populações mistas. Por sua vez, em uma situação de maior competitividade, isso gera uma espiral de declínio que faz com que as escolas freqüentadas por alunos mais pobres e alunos de cor sejam sistematicamente prejudicadas, enquanto as escolas com uma maior população de nível socioeconômico mais elevado e maior população de brancos conseguem se isolar dos efeitos da competitividade do mercado. "A debandada dos brancos" intensifica, então, o status relativo daquelas escolas já privilegiadas por forças econômicas mais fortes; a educação para o "Outro" torna-se ainda mais polarizada e dá continuidade à espiral descendente (Lauder, Hughes, 1999, p. 101-132).

Ao dizer isso, porém, precisamos ser cuidadosos para não ignorar as especificidades históricas. Os movimentos sociais, as formações ideológicas vigentes, assim como as instituições da sociedade civil e o Estado podem oferecer alguma base para o equilíbrio. Em alguns casos, nos países que têm uma história mais sólida e mais abrangente de políticas de social-democracia e uma visão positiva de liberdade coletiva, a ênfase neoliberal no mercado foi significativamente mediada. Por essa razão, conforme demonstrado por Petter Aasen, na Noruega e Suécia, por exemplo, as iniciativas de privatização na educação tiveram de enfrentar um compromisso coletivo maior que, digamos, nos Estados Unidos, Inglaterra e Nova Zelândia (Aasen, 1998). Contudo, esses compromissos, que repousam parcialmente nas relações de classe, são enfraquecidos quando a dinâmica racial entra em cena. Assim, por exemplo, a idéia de "serem todos iguais" e, conseqüentemente, estarem todos sujeitos a sentimentos coletivos similares é desafiada pelo crescimento de 
populações de imigrantes provenientes da África, Ásia e do Oriente Médio. É possível que as formas mercantilizadas de educação obtenham maior apoio quando as premissas comumente aceitas do que significa ser, digamos, norueguês ou sueco forem abaladas por populações de cor que passem a exigir o status de cidadania nacional. Por esse motivo, pode ser que os sentimentos coletivos que defendem políticas menos voltadas para o mercado se baseiem em um contrato racial não explícito, que justifica as bases ideológicas de uma "comunidade imaginária" nacional ${ }^{4}$. Isso, por sua vez, pode também gerar apoio para as políticas neoconservadoras, não devido ao compromisso neoliberal para com uma "receptividade eterna", mas, ao contrário, como uma forma de restauração cultural, como uma maneira de restabelecer um passado imaginário quando "éramos todos iguais". Por isso, é importante que qualquer análise dos atuais jogos de força que circundam a modernização conservadora leve em conta o fato de que esses movimentos estão em constante evolução; é preciso lembrar, uma vez mais, que esses jogos têm diversas dinâmicas que se cruzam, são contraditórias e que dizem respeito não somente à classe, como também à raça e ao gênero ${ }^{5}$.

A maior parte dos dados coletados por mim provém de escolas localizadas fora dos Estados Unidos, embora esses dados devessem nos fazer interromper imediatamente a rotina para pensar seriamente se desejamos adotar políticas similares aqui. Ainda assim, os Estados Unidos ainda ocupam o centro de grande parte da discussão sobre o assunto. Por exemplo, as charter schools (escolas públicas independentes estruturadas e operadas por educadores, líderes comunitários, pais e empresários da educação) e suas equivalentes nos Estados Unidos e na Inglaterra também estão sujeitas a uma análise crítica. Em ambos os países, essas escolas tendem a atrair pais que vivem e trabalham em comunidades relativamente privilegiadas. Nesse caso também "parece que quaisquer novas oportunidades estão sendo ocupadas por aqueles já privilegiados, e não pelos 'perdedores' identificados por Chubb and Moe" (Whitty, Power, Halpin, 1998; Wells et al., 1999).

4. Para saber mais sobre o contrato racial que justifica quase todos os acordos sociais em nosso tipo de sociedade, consulte Mills (1997). Estou recorrendo também à posição de Benedict, de que as próprias nações baseiam-se em "comunidades imaginadas" (Anderson, | 99|).

5. Veja, por exemplo, a análise sobre a dinâmica do gênero que cerca as políticas neoliberais em Arnot, David e Weiner ( 1999). As formas pelas quais as políticas neoconservadoras atuam, sobre e por meio de políticas de sexualidade e do corpo, encontram-se também descritas em Epstein e Johnson (1998). 
estudo sugere que existem semelhanças camufladas entre os defensores da pesquisa sobre a escola efetiva e aqueles comprometidos com "reformas" neoliberais. Ambos tendem a ignorar o fato de que características externas às escolas, tais como a pobreza, o poder político e econômico entre outras, são invariavelmente responsáveis por uma parcela muito maior nas diferenças de desempenho escolar do que os aspectos organizacionais ou as características que supostamente garantiriam uma "escola eficiente" (Whitty, Power, Halpin, 1998, p. I I2- I I3).

No geral, as conclusões são claras. "[Nas] circunstâncias atuais, a escolha de escola tende a reforçar hierarquias, assim como ampliar as oportunidades educacionais e a qualidade da educação como um todo" (p. |4). Como argumentam os autores acima, contra aqueles que acreditam que o que estamos testemunhando com o surgimento dos programas de "escolha" é a celebração pós-moderna das diferenças:

Existe um conjunto cada vez maior de indícios empíricos de que, em lugar de beneficiar os desfavorecidos, a ênfase na escolha dos pais e a autonomia da escola está prejudicando ainda mais aqueles alunos menos capazes de concorrer no mercado. Para a maioria dos grupos de desprivilegiados, ao contrário do que acontece com os poucos indivíduos que conseguem escapar das escolas na base da hierarquia de status, os novos planos parecem ser somente uma maneira sofisticada de reproduzir as diferenças tradicionais entre diferentes tipos de escolas e os alunos que as freqüentam. (p. 42)

Tudo isso nos dá razão suficiente para concordar com o argumento criterioso de Henig de que "a triste ironia do atual movimento da reforma educacional é que, devido à ênfase excessiva na identificação com propostas de escolha de escola baseadas em idéias de mercado, o saudável impulso de se levar em consideração reformas radicais para abranger problemas sociais pode ser canalizado para iniciativas que desgastem ainda mais o potencial que levaria à deliberação e resposta coletivas" (Henig, 1994, p. 222).

Esta convicção não pretende rejeitar a possibilidade nem a necessidade de reforma educacional. No entanto, é preciso considerar seriamente a probabilidade de que somente se concentrando nas características socioeconômicas externas e não simplesmente em aspectos organizacionais de escolas "bem-sucedidas", todas as escolas poderão prosperar. Eliminar a pobreza por meio de maior equiparação de renda, estabelecer programas eficientes e equiparáveis de assistência médica e moradia, e, definitivamente, recusar-se a dar continuidade às políticas camufladas e às não tão camufladas de exclusão e degradação racial, que inequivocamente ainda 
caracterizam a vida de muitas nações ${ }^{6}$, somente enfrentando esses aspectos em conjunto poderemos avançar substancialmente. A menos que os debates sobre a pedagogia crítica se baseiem no reconhecimento dessas realidades, eles próprios podem cair vítimas da armadilha de supor que as escolas podem prescindir de ajuda para superar a exclusão.

Esses achados empíricos tornam-se mais compreensíveis quando examinados à luz da análise de Pierre Bourdieu, sobre o peso relativo dado ao capital cultural como parte das atuais estratégias de mobilidade (Bourdieu, 1996). $\bigcirc$ aumento da importância do capital cultural infiltra-se em todas as instituições, de tal forma que existe um movimento relativo de deslocamento da reprodução direta dos privilégios de classe (em que o poder é transmitido em grande parte dentro das famílias por meio da propriedade econômica) para formas de privilégios de classe mediadas pela escola. Aqui, "a legação do privilégio é simultaneamente efetuada e transfigurada por meio da intercessão das instituições de ensino" (Wacquant, Prefácio para Bourdieu, 1996, p. XIII). Não se trata de conspiração; não é algo "consciente" da forma como normalmente usamos esse conceito. Pelo contrário, trata-se do resultado de uma longa cadeia de conexões relativamente independentes entre capital econômico, social e cultural acumulado diferencialmente, e que opera na esfera dos eventos diários, inclusive como vimos no contexto de escolha de escola.

Dessa maneira, embora não assuma uma posição obstinadamente determinista, Bourdieu alega que um habitus de classe tende a reproduzir "inconscientemente" as condições para sua própria reprodução. E o faz produzindo um conjunto relativamente coerente e sistematicamente característico de estratégias aparentemente naturais e inconscientes - em essência, formas de compreender e atuar no mundo que funcionam como formas de capital cultural que podem ser, e são, empregadas para proteger e ampliar o status de uma pessoa em uma esfera social de poder. Com talento, o autor compara a semelhança de habitus dos agentes sociais com a caligrafia.

Assim como a capacidade adquirida a que chamamos "caligrafia," uma forma determinada de formar letras, que sempre produz a mesma "escrita" - ou seja, traçados gráficos que, a despeito das diferenças em tamanho, material e cor da superfície usada para a escrita (folha de papel ou lousa) e o instrumento utilizado (lápis, caneta ou giz), isto é, apesar das diferenças dos meios usados para a ação de escrever,

6. Nestas, os planos de introdução da lógica de mercado na educação precisam ser vistos como parte da estrutura para evitar o corpo e a cultura do "Outro". 
apresentam uma similaridade de estilo imediatamente reconhecível ou semelhança familiar - as práticas de um único agente, ou, mais amplamente, as práticas de todos os agentes dotados de habitus semelhantes, possuem a similaridade de estilo que transforma cada um em uma metáfora para os outros, em relação ao fato de que são produtos da implementação, em diferentes campos, do mesmo esquema de percepção, pensamento e ação. (Bourdieu, 1996, p. 273)

Essa própria conexão de habitus em vários campos de poder - a facilidade de trazer os recursos econômicos, sociais e culturais de uma pessoa para relacionar-se com os "mercados" - permite a satisfação entre os mercados e o indivíduo que caracteriza, no caso, o agente de classe média. Isto produz constantemente efeitos diferenciais que não são neutros, não importa o que digam os defensores do neoliberalismo. Pelo contrário, são eles próprios resultado de uma determinada moralidade. Diferentemente das circunstâncias daquilo que pode ser mais bem chamado de "moralidade densa", em que os princípios do bem comum constituem a base ética para julgar políticas e práticas, os mercados baseiam-se em princípios agregativos, constituídos pela soma de bens e escolhas individuais. "Com base nos direitos individuais e de propriedade que permitem que os cidadãos lidem com problemas de interdependência mediante a troca", oferecem um excelente exemplo de "moralidade tênue", ao gerar tanto a hierarquia quanto a divisão baseadas no individualismo competitivo (Ball, Bowe, Gewirtz, 1994, p. 24). E, nessa competição, o perfil geral dos vencedores e dos perdedores foi identificado empiricamente.

\section{CURRÍCULOS NACIONAIS E EXAMES NACIONAIS}

Já demonstrei que existem conexões entre, no mínimo, duas dinâmicas que operam nas reformas neoliberais: os mercados "livres" e a vigilância ampliada. Isso pode ser observado pelo fato de que, em diversos contextos, a mercantilização é acompanhada por um conjunto de determinadas políticas para os "produtores", para os profissionais que trabalham com educação. Essas políticas têm sido rigorosamente reguladoras e bastante úteis na reconstituição do senso comum. Assim como no caso da conexão entre os exames nacionais e os indicadores de desempenho publicados na forma do ranking de escolas, essas políticas foram elaboradas tendo em vista a preocupação quanto à supervisão, regulação e avaliação externas de desempenho e têm sido cada vez mais influenciadas por pais que possuem aquilo que é visto como um capital econômico, social e cultural "apropriado" (Mentor et al., 1997, p.8). Essa preocupação com a supervisão e a regulação externas não se 
deve somente a uma forte desconfiança que paira sobre os "produtores" (por exemplo os professores) e à necessidade de garantir que as pessoas continuamente tomem iniciativas próprias. Está também nitidamente ligada tanto ao sentido neoconservador da necessidade de um "retorno" a um passado perdido, de padrões elevados, disciplina, reverência e conhecimento "real", como à própria capacidade da classe média profissional de estabelecer uma esfera de autoridade dentro do Estado para defender seu próprio compromisso com técnicas e eficiência de gestão. $\bigcirc$ enfoque em eficiência da gestão desempenha importante papel aqui, considerado útil por muitos neoliberais e neoconservadores.

Ocorreu uma mudança na relação entre o Estado e os "profissionais". Em essência, a mudança em direção a um pequeno Estado forte, cada vez mais orientado pelas necessidades do mercado, parece trazer inevitavelmente consigo uma redução no poder e no status profissional (p. 57). O gerencialismo que desempenha aqui um papel central é em grande parte responsável por "realizar a transformação cultural que muda as identidades profissionais para torná-las mais sensíveis às necessidades do cliente e ao julgamento externo". Tem como objetivo justificar e fazer com que as pessoas internalizem alterações importantes nas práticas profissionais. Tanto aproveita a energia quanto desestimula a dissidência (p. 9).

Não há necessariamente contradição entre um conjunto global de interesses e processos de mercantilização e desregulação - tais como os planos de empréstimo e escolha - e um conjunto ampliado de processos reguladores - tais como os planos de currículo nacional e exame nacional. "A forma de regulação permite que o Estado 'fique no comando' no que diz respeito aos objetivos e processos da educação a partir do mecanismo de mercado" (p. 24). Esse "comando" quase sempre aparece na forma de padrões nacionais, currículos nacionais e exames nacionais. Atualmente, essas formas estão avançando nos Estados Unidos e são objeto de considerável controvérsia; algumas ultrapassam linhas ideológicas e exibem algumas das tensões existentes entre os diversos elementos contidos sob o guarda-chuva da modernização conservadora.

Tenho afirmado que, paradoxalmente, um currículo nacional e principalmente um programa de exame nacional constituem os primeiros e mais importantes passos em direção a maior mercantilização da educação. Na verdade, fornecem os mecanismos de dados comparativos que os "consumidores" precisam para fazer com que os mercados funcionem como tal (Apple, 1996, p. 23). Na falta desses mecanismos, não há base comparativa de informações para se fazer a "escolha". No entanto, não precisamos demonstrar essas formas de regulação no vácuo. As- 
sim como os mercados neoliberais que analisei na seção anterior, essas formas também foram instituídas na Inglaterra e existe suficiente material de pesquisa que pode e deve nos ajudar a ter a devida cautela para assumir esse caminho.

É possível que se queira defender que um conjunto nacional de padrões, currículos nacionais e exames nacionais possam fornecer as condições para uma "moralidade densa". Afinal, essas reformas reguladoras supostamente baseiam-se em valores e sentimentos comuns que também criam espaços sociais em que as questões de preocupação comuns a todos possam ser debatidas e submetidas a questionamento moral (Ball, Bowe, Gewirtz, 1994, p. 23). No entanto, o que conta como sendo o "comum", e de que forma e por quem isso é na verdade determinado, é mais tênue do que denso.

É o caso da Inglaterra e do País de Gales, onde, embora o currículo nacional hoje tão solidamente implantado seja claramente prescritivo, ele não conseguiu ser sempre a camisa-de-força que se alegava muitas vezes que seria. Como alguns pesquisadores documentaram, não só é possível que as políticas e a legislação sejam interpretados e adaptados, como também isso parece inevitável. Dessa forma, o currículo nacional não está "tanto sendo 'implementado' nas escolas quanto sendo 'recriado', nem tanto 'reproduzido' quanto 'produzido'" (Power, Halpin, Fitz, I994, p. 38).

Em termos gerais, é quase um truísmo afirmar que não existe um modelo linear simplista de formação, distribuição e implementação de políticas. Cada etapa do processo contém sempre mediações complexas. Existe uma complexa política acontecendo dentro de cada grupo e entre esses grupos e as forças externas na elaboração das políticas, na sua redação como mandato legislativo, na sua distribuição e na sua recepção no que diz respeito à prática (Ranson, 1995). Dessa forma, o Estado pode determinar mudanças no currículo, no sistema de avaliação ou nas políticas (mudanças essas realizadas por meio de conflitos, compromissos e manobras políticas), mas os redatores das políticas e dos currículos podem ser incapazes de controlar os significados e implementações de seus textos. Todos os textos são documentos que "vazam", sujeitos a "recontextualização" em cada etapa do processo (Kim Cho, Apple, 1998, p. 269-290).

Contudo, este princípio geral pode ser um pouco romântico demais. Nada disso acontece em um campo uniforme. Assim como acontece com os planos de mercadologia, existem diferenças bastante reais em jogo na habilidade que uma pessoa tem de influenciar, mediar, transformar ou rejeitar uma norma ou um processo regulador. Isso posto, é importante reconhecer que um "modelo de controle 
estatal" - com a suposta linearidade de cima para baixo - é por demais simplista e que existe sempre a possibilidade de intervenção e influência humanas. Porém, isso não significa que tal intervenção e influência tenham poder (Ranson, 1995, p. 437).

O caso do currículo nacional e do exame nacional na Inglaterra e no País de Gales reflete as tensões existentes nesses dois aspectos. Na verdade, o currículo nacional original e imposto nesses países foi objeto de contenda. Sua primeira versão era detalhada e específica demais, e, por isso, sofreu alterações importantes no âmbito da nação, da comunidade, da escola e, por fim, da sala de aula. Embora o currículo nacional tenha sido objeto de conflito, de mediação e de algumas alterações em seu conteúdo, em sua organização e nas suas formas invasivas e morosas de avaliação, seu poder total é demonstrado por meio da reconfiguração radical do próprio processo de seleção, organização e avaliação do conhecimento. Ele alterou radicalmente o terreno da educação como um todo. Suas divisões por tópicos "fornecem mais limites que escopos para liberdade de ação". Os "objetivos-padrão de resultados" obrigatórios consolidam esses limites. "A imposição do exame nacional impõe o currículo nacional como a estrutura dominante do trabalho dos professores, a despeito de quaisquer oportunidades que possam ter de burlar ou reformular o currículo" (Hatcher, Troyna apud Ranson, 1995, p. 438).

Portanto, não basta afirmar que o mundo da educação é complexo e sofre inúmeras influências. $\bigcirc$ objetivo de qualquer análise que se pretende séria é ir além dessas conclusões genéricas. Em vez disso, precisamos "discriminar níveis de influência no mundo", para avaliar a eficácia relativa dos fatores envolvidos. Conseqüentemente, embora seja claro que enquanto o currículo nacional e os exames nacionais que atualmente existem na Inglaterra e no País de Wales tenham surgido devido a uma complexa interação de forças e influências, fica igualmente claro que "o controle do Estado tem a palavra final" (Ranson, 1995, p. 438).

Os currículos nacionais e os exames nacionais sem dúvida geraram conflito sobre os assuntos tratados. Em parte, criaram espaços sociais para as questões morais (logicamente, essas questões morais sempre foram levantadas por grupos desprivilegiados). Desta maneira, ficou claro para muitas pessoas que a criação de exames obrigatórios e redutivos, que davam ênfase à memória e à abstração descontextualizada, puxou o currículo nacional para uma determinada direção - a de estimular um mercado educacional seletivo em que alunos de elite e escolas de elite, com uma ampla gama de recursos, seriam bem servidos (ainda que limitadamente). Diversos grupos alegaram que esses exames simplistas, redutivos e detaIhados, feitos com papel e caneta, "tinham o potencial de causar danos enormes", 
situação tornada ainda pior pelo fato de os exames serem onerosos em termos do tempo consumido e dos registros. Os professores conseguiram um apoio substancial quando, em grupo e em um memorável ato público de protesto, decidiram boicotar a aplicação das provas. Isso também provocou um sério questionamento sobre a arbitrariedade, a inflexibilidade e o caráter exageradamente prescritivo do currículo nacional. Embora o currículo continue a ser inerentemente problemático e o sistema de avaliação ainda contenha diversos elementos perigosos e onerosos, as atividades organizadas contra eles sem dúvida causaram um impacto.

No entanto, infelizmente, a história não termina aqui. Em meados da década de 90, embora o governo tenha retrocedido parcialmente nas formas reguladoras do seu programa de exame constante e redutivo, ficou mais claro que o desenvolvimento do exame e a especificação do conteúdo haviam sido "seqüestrados" por pessoas ideologicamente comprometidas com pegadogias tradicionais e com a idéia de uma seleção mais rigorosa. Os efeitos residuais são tanto materiais quanto ideológicos. Incluem uma ênfase contínua na tentativa de imprimir um "rigor [que] falta na prática da maioria dos professores,... julgando o progresso somente por aquilo que pode ser verificado por meio de provas desse tipo" e o desenvolvimento de uma "visão muito hostil quanto à responsabilidade dos professores", visão esta entendida como "parte de uma investida mais ampla da política para se tirar o controle dos serviços públicos pelos seus profissionais e estabelecer um controle exercido pelo consumidor, por meio de uma estrutura de mercado" (O'Hear, 1994, p. 55-68).

Os autores de uma análise extremamente minuciosa dos sistemas de avaliação recentemente instituídos na Inglaterra e no País de Gales fornecem um resumo do que ocorreu. Gipps e Murphy alegam que se tornou cada vez mais óbvio que o programa nacional de avaliação conectado ao currículo nacional está cada vez mais dominado pelos modelos tradicionais de exames e pelas suposições sobre ensino e aprendizagem subjacentes a eles. Ao mesmo tempo, as questões referentes à eqüidade estão se tornando muito menos visíveis. No cálculo dos valores agora vigentes no Estado regulador, a eficiência, a velocidade e o controle de custos substituem preocupações mais importantes sobre justiça social e educacional. A pressão para implementar rapidamente esse tipo de avaliação tem significado que "a velocidade do desenvolvimento das provas é tão grande, e as mudanças no currículo e na avaliação tão uniformes, que [existe] pouco tempo para realizar análises detalhadas e submeter as provas a testes para garantir que sejam, tanto quanto possível, as mais justas para todos os grupos" (Gipps, Murphy, 1994, p. 204). As condições de "moralidade tênue" - nas quais domina o indivíduo competitivo do mercado, e a 
justiça social cuida, de alguma forma, de si própria - estão aqui reproduzidas. A combinação do mercado neoliberal com o Estado regulador, então, realmente "funciona". Porém, funciona de maneira que as metáforas do livre mercado, do mérito e do esforço camuflam a realidade diferencial produzida. Se por um lado isso torna ainda mais fundamental a adoção de uma pedagogia social e culturalmente crítica, faz também com que ela seja muito mais difíil de realmente ser colocada em prática.

Para compreender como isso ocorre, é recomendável ler a análise de Basil Bernstein (1990, 1996) sobre os princípios gerais pelos quais o conhecimento e as políticas ("textos") passam de uma arena a outra. Como Bernstein nos faz lembrar, quando se fala sobre mudanças educacionais existem três campos com os quais devemos nos preocupar. Cada um deles tem suas próprias regras de acesso, regulação, privilégios e interesses específicos: I) o campo da "produção" no qual se constrói o novo conhecimento; 2) o campo da "reprodução" no qual a pedagogia e o currículo são realmente colocados em ação nas escolas; e, entre esses dois outros, 3) o campo da "recontextualização", no qual os discursos do campo da produção são apropriados e, em seguida, transformados em discurso e recomendações pedagógicas. Essa apropriação e recontextualização do conhecimento para fins educacionais se autogoverna por meio de dois conjuntos de princípios. $\bigcirc$ primeiro, deslocação, indica que existe sempre uma apropriação seletiva do conhecimento e do discurso do campo da produção. $O$ segundo, relocação, aponta para o fato de que quando o conhecimento e o discurso do campo da produção são trazidos para o campo da recontextualização, ficam sujeitos às transformações ideológicas devido aos diversos interesses especializados e/ou políticos cujos conflitos estruturam o campo da recontextualização (Evans, Penney, 1995; Wong, Apple, no prelo).

Um bom exemplo disso, e que corrobora a análise de Gipps e Murphy sobre a dinâmica dos currículos nacionais e dos exames nacionais durante suas mais recentes iterações, pode ser encontrado no processo pelo qual o conteúdo e a organização do currículo nacional obrigatório em educação física foi objeto de contenda e, por fim, instituído na Inglaterra. Nesse caso, formou-se um grupo de trabaIho constituído de acadêmicos, tanto de dentro como de fora da área da educação física, diretores de escolas particulares e públicas, atletas renomados e líderes empresariais (mas não-professores).

As primeiras políticas de currículo sugeridas pelos grupos foram relativamente mistas, do ponto de vista educacional e ideológico, levando-se em conta o campo da produção do conhecimento dentro da educação física. Isto é, continham tanto elementos críticos e progressistas quanto elementos da restauração conserva- 
dora, assim como perspectivas acadêmicas nos campos especializados da universidade. Porém, à medida que esses especialistas terminavam de discorrer para em seguida fazer recomendações de ação, passavam a se aproximar cada vez mais dos princípios da restauração. A ênfase sobre a eficiência, habilidades básicas e teste de desempenho, sobre o controle social do corpo e sobre normas competitivas, por fim, venceu. Da mesma forma que a captura do mercado pela classe média, tampouco se tratava nesse caso de conspiração. Pelo contrário, era resultado de um processo de "sobredeterminação". Isto é, não se devia a uma imposição dessas normas, mas sim a uma combinação de interesses no campo da recontextualização: um contexto econômico em que os gastos públicos estavam sob rígida vigilância e que exigia redução de despesas em todas as áreas; funcionários do governo que se opunham aos "supérfluos" e intervinham constantemente para instituir somente uma seleção das recomendações (conservadoras, que preferivelmente não tivessem partido dos "acadêmicos profissionais"); ataques ideológicos a abordagens críticas, progressistas ou voltadas para a educação física infantil, e um discurso dominante sobre "ser pragmático". Esses aspectos apareceram em conjunto no campo da recontextualização e ajudaram a garantir, na prática, que os princípios conservadores fossem reinscritos nas políticas e na legislação, e que as formas críticas fossem vistas como ideológicas demais, por demais onerosas ou carecendo de praticidade (Evans, Penney, 1995). Os "padrões" foram mantidos; críticas foram ouvidas, mas basicamente sem causar efeito substancial; as normas do desempenho competitivo passaram a ocupar posição central e foram empregadas como dispositivos reguladores, os quais serviram para privilegiar grupos específicos, assim como os mercados o fizeram. Desse modo funciona a democracia na educação.

\section{PENSAMENTO ESTRATÉGICO}

Neste artigo, por enquanto, levantei sérias questões acerca dos esforços relativos à atual "reforma" educacional em andamento em várias nações. Utilizei de forma abundante, mas não exclusiva, pesquisas sobre a(s) experiência(s) dos ingleses com vistas a documentar alguns dos efeitos diferenciais ocultos de duas estratégias relacionadas entre si - propostas de mercado de inspiração neoliberal e propostas de regulação de inspiração neoliberal, neoconservadora e gerencial da classe média. Tendo por base a análise histórica de Herbert Kliebard, descrevi como interesses diferentes, com visões sociais e educacionais diferentes, competem pelo domínio no campo social do poder circunjacente à política e à prática educacionais. 
Nesse processo, documentei algumas das complexidades e desequilíbrios nesse campo do poder. Essas complexidades e desequilíbrios resultam em uma moralidade "tênue", em lugar de uma moralidade "densa", e na reprodução tanto das ideologias e formas pedagógicas e curriculares dominantes como dos privilégios sociais que as acompanham. Sugeri que o vigor retórico dos discursos da pedagogia crítica precisa combater essas condições ideológicas e materiais em transformação. A pedagogia crítica não pode ocorrer e não ocorrerá no vácuo. A não ser que realmente enfrentemos essas profundas transformações de direita e pensemos a tática contra elas, obteremos pouco resultado na criação de um senso comum contra a hegemonia ou na construção de uma aliança contra essa hegemonia. $\bigcirc$ crescimento dessa estranha combinação de lógica de mercado e Estado regulador, o movimento em direção a um ensino e currículos acadêmicos "tradicionais", a habilidade dos grupos dominantes de exercer a liderança nessa luta e as mudanças no senso comum que as acompanham - não se pode apenas almejar que tudo isso simplesmente desapareça. Ao contrário, é preciso encarar isso de frente e fazer uma análise crítica de nós mesmos.

Isso posto, gostaria, no entanto, de apontar um paradoxo oculto na minha análise. Embora grande parte da pesquisa realizada recentemente por mim e por outros tenha sido sobre os processos e efeitos da modernização conservadora, há perigos nesse enfoque sobre os quais deveríamos estar conscientes. A pesquisa sobre a história, as políticas e as práticas das "reformas" e movimentos educacionais e sociais de direita permitiu-nos mostrar as contradições e os efeitos desiguais de tais políticas e práticas. Possibilitou a rearticulação das reivindicações de justiça social com base em uma evidência sólida. Tudo isso é muito bom. Todavia, no processo, um dos efeitos latentes foi a estruturação gradual das questões educacionais, em grande parte, nos termos da agenda conservadora. As próprias categorias - mercados, escolha, currículos nacionais, exames nacionais, padrões - trazem o debate para a arena estabelecida pelos neoliberais e neoconservadores. A análise de "o que é" levou a negligenciar-se "o que deveria ser". Assim, houve uma diminuição de discussões substantivas em larga escala sobre alternativas possíveis para a maneira de ver as políticas e as práticas neoliberais e neoconservadoras, discussões essas que avançariam para muito além delas (Seddon, 1997).

Por esse motivo, pelo menos parte de nossa tarefa pode ser política e conceitualmente complexa, mas pode ser expressa com simplicidade. A longo prazo, precisamos "desenvolver um projeto político que seja ao mesmo tempo local e passível de generalização, sistemático sem fazer reivindicações masculinistas e 
eurocêntricas quanto às verdades essenciais e universais sobre os seres humanos" (Luke, 1995). Outra parte de nossa tarefa, no entanto, tem de ser e é mais imediata, de cunho mais educacional. É preciso elaborar e tornar amplamente disponíveis políticas e práticas alternativas críticas, progressistas, defensáveis, articuladas e sólidas sobre currículo, ensino e avaliação. Mas isso também deve ser feito com o devido reconhecimento da natureza mutável do campo social do poder e da importância de se pensar de forma tática e estratégica. Permitam-me especificar.

Por exemplo, nos Estados Unidos a revista Rethinking Schoo/s, cada vez mais popular, tem sido um fórum importante para a crítica social e educacional, bem como para descrições de práticas educacionais críticas em escolas e comunidades. Às vezes influenciados diretamente pelo trabalho de Paulo Freire e por outros educadores que o elaboraram e ampliaram, e outras vezes por diversas tradições educacionais radicais originárias dos EUA, Rethinking Schools e organizações nacionais emergentes ${ }^{7}$ construíram em conjunto espaços para educadores críticos, ativistas políticos e culturais, estudiosos radicais etc. ensinarem uns aos outros, oferecerem crítica construtiva aos trabalhos uns dos outros e formularem um conjunto de respostas mais coletivas às políticas educacionais e sociais destrutivas advindas da restauração conservadora.

Ao usar a frase "respostas coletivas", no entanto, preciso enfatizar que ela não significa nada parecido com "centralismo democrático" em que um pequeno grupo ou um quadro de um partido fala pela maioria e estabelece a posição "adequada”. Dado o fato de haver diversos movimentos emancipatórios cujas vozes são ouvidas em publicações como Rethinking Schoolse em organizações semelhantes à National Coalition of Educational Activists - posições anti-racistas e pós-coloniais, formas radicais de multiculturalismo, homossexuais e lésbicas, múltiplas vozes feministas, neomarxistas e socialistas democratas, "verdes" etc. - uma maneira mais apropriada de olhar o que está acontecendo é chamá-la de unidade descentrada. Múltiplos projetos progressistas, múltiplas "pedagogias críticas" são articuladas. Como em Freire, cada uma delas relaciona-se com as lutas reais, em instituições reais, em comunidades reais. Evidentemente, não devemos ser românticos a esse respeito. Existem diferenças muito reais - políticas, epistemológicas, e/ou educacionais - nessas diversas vozes. Mesmo assim, elas estão unidas em sua oposição às forças envolvidas na nova aliança hegemônica conservadora. Existem tensões, mas a unidade

7. Tais como a National Coalition of Educational Activists [Coalizão Nacional de Ativistas Educacionais]. 
descentrada permaneceu forte o suficiente para que cada grupo constituinte apóie as lutas dos outros.

E isso não é tudo. Ao mesmo tempo em que esses movimentos estão sendo estruturados, educadores críticos procuram também ocupar os espaços oferecidos pelos distribuidores das publicações existentes sobre a "corrente principal" para publicar livros que oferecem respostas críticas para as perguntas dos professores do tipo "O que faço na segunda-feira?" em uma era conservadora. Esse espaço foi por muito tempo ignorado por muitos teóricos da pedagogia crítica. Algumas dessas tentativas obtiveram enorme êxito. Vou dar um exemplo. Uma organização que congrega um número considerável de "profissionais" nos Estados Unidos - a Association for Supervision and Curriculum Development [Associação para Supervisão e Desenvolvimento de Currículo] - ASCD - publica livros que são distribuídos a cada ano para seus mais de 150 mil membros, a maioria constituída de professores ou dirigentes de escolas de ensino fundamental e médio. A ASCD não tem se mostrado uma organização muito progressista, preferindo publicar material predominantemente técnico e abertamente despolitizado. No entanto, tem-se preocupado com o fato de suas publicações não representarem os educadores que fazem crítica social e cultural. Por isso, a editora tem procurado formas de estender sua legitimidade para uma esfera mais ampla de educadores. Devido a esse problema de legitimidade e em vista do grande número de associados, tornou-se claro, para algumas pessoas que pertenciam às tradições educacionais críticas nos Estados Unidos, que talvez fosse possível convencer a ASCD a publicar e fazer circular amplamente material que demonstrasse os sucessos práticos reais de modelos críticos de currículo, ensino e avaliação na solução de problemas reais nas escolas e comunidades, especialmente com a classe trabalhadora, crianças pobres e crianças de cor.

Depois de intensas negociações que garantiram a ausência de censura, um colega e eu resolvemos publicar um livro (Apple, Beane, 1995) que traria exemplos práticos do poder das abordagens críticas freirianas e similares, operando em salas de aula e comunidades. O livro não apenas foi distribuído para os 150 mil membros da organização, como também vendeu 100 mil cópias adicionais. Dessa forma, perto de 250 mil cópias de um volume que conta as estórias práticas de lutas bemsucedidas de educadores que seguem a teoria crítica em escolas reais estão agora nas mãos de educadores que todo dia enfrentam problemas semelhantes ${ }^{8}$. Trata-se

8. Traduções deste volume foram ou deverão ser publicadas, entre outros países, no Brasil e em Portugal. 
de uma intervenção importante. Embora não haja garantia de que os professores serão sempre progressistas (nem há qualquer garantia de que aqueles que são progressistas em questões de classe e sindicato sejam igualmente progressistas em questões de gênero, sexualidade e raça), muitos professores têm intuições social e pedagogicamente críticas. No entanto, quase nunca sabem como colocar essas intuições na prática, porque não conseguem imaginá-las em operação nas situações do dia-adia. Por causa disso, percepções teórico-críticas e políticas não têm onde se encaixar, em termos de sua corporificação, em situações pedagógicas concretas, nas quais as políticas de currículo e ensino têm de ser aplicadas. Essa é uma lacuna trágica, e preenchê-la de forma estratégica é sem dúvida fundamental. Assim, precisamos usar e ampliar os espaços em que as histórias pedagógicas críticas possam ser colocadas à disposição para que não permaneçam apenas no plano teórico ou retórico. A publicação e ampla distribuição de Democratic Schools ilustram uma maneira de se usar e ampliar tais espaços de forma que as posições educacionais críticas freirianas e similares pareçam passíveis de ser implementadas nas instituições "normais" tais como escolas e comunidades locais.

Embora crucial, isso não é suficiente para desconstruir as políticas de restauração na educação. A direita mostrou como as mudanças do senso comum são importantes na luta pela educação. É nossa tarefa ajudar a reconstruí-la coletivamente, restabelecendo o sentimento de que uma ética "densa" e uma democracia "densa" são verdadeiramente possíveis na atualidade.

Isso não pode ser feito sem darmos maior atenção a duas coisas. A primeira - as transformações materiais e ideológicas que a direita efetuou -, constituíram um tópico central deste artigo. No entanto, há um outro elemento ao qual se deve dar ênfase - a estruturação em larga escala de movimentos contra a hegemonia que ligam as lutas educacionais àquelas em outras frentes e também auxiliam na criação de novas lutas e na defesa das já existentes, dentro das próprias instituições educacionais. No contexto conservador atual há, contudo, características de alguns dos materiais sobre pedagogia crítica que tornam essa ação mais difícil ainda.

No passado, adverti para o fato de a política estilística de alguns de nossos trabalhos mais "avançados" obrigar o leitor a fazer todo o trabalho (Apple, 1998, 1999). Neologismo após neologismo, reinam absolutos. Como Dennis Carlson e eu (1998) argumentamos em outro contexto, o discurso da pedagogia crítica nas formas freirianas e feministas vem sendo influenciado de forma crescente pelas teorias pós-modernas. Embora tenha sido muito útil na reconceituação do campo e suas políticas, isso também expôs o discurso à crítica de ter-se tornado muito teóri- 
co, abstrato, esotérico e sem ligação com os conflitos e lutas em que professores, estudantes e ativistas atuam. Henry Giroux (1992) e outros defenderam tais discursos como necessários na pedagogia crítica, pois para se reconstruir o mundo devese primeiro aprender a falar uma nova linguagem e "novas idéias requerem novos termos". Sem dúvida isso é correto. Na verdade, essa foi a posição que conscientemente adotei quando apresentei as teorias de Gramsci e Habermas pela primeira vez na educação, no início da década de 1970.

No entanto, uma vez reconhecido isso, devido ao sucesso real da estratégia de "falar com clareza" adotada pelos neoliberais e neoconservadores, algumas das críticas feitas ao material sobre a pedagogia crítica são convincentes. Embora grande parte desse material seja rico e provocativo, parte dele éconceitual e politicamente confuso, e provoca confusão. Parte dele está distanciado das materialidades terrenas das lutas educacionais/culturais, políticas e econômicas do dia-a-dia. Parte dele romantiza $\mathrm{O}$ aspecto cultural à custa de tradições igualmente poderosas de análises que se baseiam na economia e no Estado. E parte dele coloca tanta ênfase no "pós" que se esquece das realidades estruturais que impõem limites a pessoas reais, em instituições reais, no dia-a-dia.

Dessa forma, como muitos analistas têm afirmado repetidamente, é necessário um esforço muito maior para enraizar o discurso da pedagogia crítica nas lutas concretas de grupos diversos e identificáveis. Grande parte desse material precisa desqualificar bem menos as tradições anteriores à teoria crítica que, com razão, continuam a influenciar ativistas educacionais e culturais. Igualmente importante, como observei há pouco, é a necessidade de tornar muito mais visível do que temos sido capazes de fazê-lo aquilo em que as pedagogias críticas se assemelham na realidade, quando colocadas em prática - não apenas em suas elaborações teóricas. Infelizmente, conquanto não se possa dizer que as mobilizações de direita obtiveram pouco sucesso na criação de um senso comum reacionário sobre educação (e até mesmo entre muitos educadores), temos de admitir que os estilos lingüísticos de grande parte dos trabalhos da teoria crítica são rotulados de "arrogantes" (algumas vezes com propriedade) e isolam-se a si mesmos dos muitos professores e ativistas radicais que desejariam apoiá-los.

É tarefa árdua a de não ser descuidado. É tarefa árdua escrever de forma que as nuanças políticas e teóricas não sejam sacrificadas no altar do senso comum, mas também de forma que o trabalho árduo da leitura possa realmente valer a pena para quem lê. E é uma tarefa árdua e demorada escrever em múltiplos níveis. Mas se não o fizermos, os neoliberais e neoconservadores o farão. E ficaremos numa 
situação muito pior. Nessa época de restauração conservadora, os diversos projetos da educação crítica são realmente cruciais. Uma boa dose de realidade não fará mal, e acredito que os tornará na verdade mais eficazes a longo prazo.

\section{REFERÊNCIAS BIBLIOGRÁFICAS}

AASEN, P. What happened to social democratic progressivism in Scandinavia?: restructuring education in Sweden and Norway. Norway: Department of Education, Norwegian University of Science and Technology, 1998. [unpublished paper]

ANDERSON, B. Imagined communities. New York: Verso, 1991.

APPLE, M.W. Cultural politics and education. New York: Teachers College Press, 1996.

. Educating the "right" way: markets, standards, god, and inequality. New York: Routledge, 200I.

. Education and power. 2. ed. New York: Routledge, 1995.

. Official knowledge. 2. ed. New York: Routledge, 2000.

. Power, meaning and identity. New York: Peter Lang, 1999.

. Teachers and texts. New York: Routledge, 1998.

APPLE, M. W.; BEANE, J. A. (eds.) Democratic schools. Washington: Association for Supervision and Curriculum Development, 1995.

- Democratic schools: lessons from the chalk face. Buckingham: Open University Press, 1999.

ARNOT, M.; DAVID, M.; WEINER, G. Closing the gender gap. Cambridge: Polity Press, 1999.

BALL, S.; BOWE, R.; GEWIRTZ, S. Market forces and parental choice. In: TOMLINSON, S. (ed.). Educational reform and its consequences. London: IPPR/Rivers Oram Press, 1994.

BERNSTEIN, B. Pedagogy, symbolic control, and identity. Bristol: Taylor and Francis, 1996.

. The Structuring of pedagogic discourse. New York: Routledge, 1990.

BOURDIEU, P. Distinction. Cambridge: Harvard University Press, 1984.

. The State nobility. Stanford: Stanford University Press, 1996.

BROWN, P. Cultural capital and social exclusion. In: HALSEY, A. H. et al. (eds.). Education: culture, economy, and society. New York: Oxford University Press, 1997. p.736-749. 
CARLSON, D.; APPLE, M. W. Critical educational theory in unsettling times. In: (eds.). Power/knowledge/pedagogy. Boulder: Westview Press, 1998. p. I-38.

CHUBB, J.; MOE, T. Politics, markets, and american schools. Washington, DC: Brookings Institution, 1990.

CLARK, J; NEWMAN, J. The Managerial state. Thousand Oaks: Sage, 1997.

DUNIER, M. Sidewalk. New York: Farrar, Straus and Giroux, 1999.

EPSTEIN, D.; JOHNSON, R. Schooling sexualities. Philadelphia: Open University Press, 1998.

EVANS, J.; PENNEY, D. The Politics of pedagogy. Journal of Education Policy, n. 10, p.27-44, Jan. 1995.

FINE, M.; WEIS, L. The Unknown city. Boston: Beacon Press, 1998.

FRASER, N. Justice interruptis. New York: Routledge, 1997.

. Unruly practices. Minneapolis: University of Minnesota Press, 1989.

GEWIRTZ, S.; BALL, S.; BOWE, R. Markets, choice, and equity in education. Philadelphia: Open University Press, 1995.

GILLBORN, D. Race, nation, and education. London: Institute of Education, University of London, 1997. [unpublished paper]

. Racism and reform. British Educational Research Journal, n. 23, Jun. 1997a.

GILLBORN, D.; YOUDELL, D. Rationing education. Philadelphia: Open University Press, 2000 .

GIPPS, C.; MURPHY, P. A Fair test. Philadelphia: Open University Press, 1994.

GIROUX, H. Border crossings. New York: Routledge, 1992.

HENIG, J. R. Rethinking schoo/ choice: limits of a market metaphor. Princeton: Princeton University Press, 1994.

HERRNSTEIN, R.; MURRAY, C. The bell curve. New York: Free Press, 1994.

HIRSCH, E.D. Jr. The Schools we want and why we don't have them. New York: Doubleday, 1996.

KIM CHO, M.; APPLE, M. W. Schooling, work, and subjectivity. British Journal of Sociology of Education, n. 19, p. 269-290, Summer 1998.

KINCHELOE, J.; STEINBERG, S.; GREESON, A. (eds.). Measured lies. New York: St. Martin's Press, 1997. 
KLIEBARD, H. The Struggle for the american curriculum. 2. ed. New York: Routledge, 1995. LAUDER, H.; HUGHES, D. Trading in futures. Philadelphia: Open University Press, 1999. LUKE, A. Textual politics. Bristol: Taylor and Francis, 1995. p.VI-VII. [Series Editor's Introduction to Jay Lemke.]

McCARTHY, C. The Uses of culture. New York: Routledge, 1998.

MCCARTHY, C.; CRICHLOW, W. (orgs.). Race, identity, and representation in education. New York: Routledge, 1994.

McCULLOCH, G. Privatising the past. British Journal of Educational Studies, n. 45, Mar. 1997.

MENTOR, I. et al. Work and identity in the primary school. Philadelphia: Open University Press, 1997.

MIDDLETON, S. Disciplining sexualities. New York: Teachers College Press, 1998.

MILLS, C. W. The racial contract. Ithaca: Cornell University Press, 1997.

O'HEAR, P. An Alternative national curriculum. In: TOMLINSON, S. (ed.). Educational reform and its consequences. London: IPPR/Rivers Oram Press, 1994. p.66.

OLSSEN, M. Defense of the welfare state and of publicly provided education. Journal of Education Policy, n. II, May 1996.

OMI, M.; WINANT, H. Racial formation in the United States. New York: Routledge, 1994. POWER, S.; HALPIN, D.; FITZ, J. Underpinning choice and diversity. In: TOMLINSON, S. (ed.). Educational reform and its consequences. London: IPPR/Rivers Oram Press, 1994.

RANSON, S. Theorizing educational policy. Journal of Education Policy, n. 10. p.427, Jul. 1995.

RURY, J.; MIREL, J. The political economy of urban education. In: APPLE, M. W. (ed.). Review of research in education, v.22. Washington: American Educational Research Association, 1997. p.49-1 10.

SEDDON, T. Markets and the English. British Journal of Sociology of Education, n. 18, p. 165-166, Jun. 1997.

SELDEN, S. Inheriting shame. New York: Teachers College Press, 1999.

SWARTZ, D. Culture and power. Chicago: University of Chicago Press, 1997.

TEITELBAUM, K. Schooling for good rebels. New York: Teachers College Press, 1996.

WACQUANT, L. Foreword. In: BOURDIEU, P. The State nobility. Stanford: Stanford University Press, 1996. p. XIII. 
WELLS, A. S. et al. Beyond the rhetoric of charter school reform. Los Angeles: University of California at Los Angeles, Graduate School of Education and Information Studies, 1999.

WHITTY, G. Creating quasi-markets in education. In: APPLE, M. W. (ed.). Review of research in education, v. 22. Washington: American Educational Research Association, 1997. p.3-47.

Sociology and the problem of radical educational change. In: FLUDE, M.; AHIER, J. (eds.). Educability, schools, and ideology. London: Halstead Press, 1974. p. I I2-I37.

WHITTY, G.; EDWARDS, T.; GEWIRTZ, S. Specialization and choice in urban education. London: Routledge, 1993.

WHITTY, G.; POWER, S.; HALPIN, D. Devolution and choice in education: the school, the state, and the market. Buckingham: Imprenta Open University Press, 1998.

WONG, T.-H.; APPLE, M. W. Rethinking the education/state formation connection. British Journal of Sociology of Education. [in press] 